GSA Data Repository 2017030

\title{
Barrier island migration dominates ecogeomorphic feedbacks and drives salt marsh loss along the Virginia Atlantic Coast, USA
}

\author{
Charles D. Deaton, Christopher J. Hein, Matthew L. Kirwan
}

\section{SUPPLEMENTAL MATERIALS}

\section{Supplemental Methods}

Historical backbarrier marsh and open-water areas along the Virginia barrier islands were derived through digitizing the marsh-water boundary at map scale $(1: 20,000)$ from a series NOS T-sheets. A list of T-sheets used are provided in Table DR1.

Errors in shoreline movement rates were determined similarly to Hapke et al. (2011). The uncertainty of each mapped shoreline was input to the Digital Shoreline Analysis System (DSAS: Thieler et al., 2008), which returned a linear regression along each transect (50 meter spacing), and also provided a $2 \sigma(95.5 \%)$ confidence interval calculated from each shoreline's uncertainty value. Island uncertainties were calculated as the average uncertainty of each transect crossing an island, divided by the number of transects. This method of calculating islandaveraged uncertainty assumes that each transect uncertainty is independent of all other transects, which is likely not a condition that is fully met by barrier island shorelines (Hapke et al., 2011). While our reported uncertainties are not especially conservative, we believe this approach to be superior to a simple regional average, as it captures the benefit of using multiple transects to improve the precision of shoreline movement rates.

Errors in marsh and open-water area mapping were calculated by obtaining the perimeter of all areas of marsh and water within each subdivision (bayshed, barriershed, or all islands) and multiplying that perimeter (or cross-sectional area, in the case of tidal prism) by the uncertainty introduced during mapping, after Hapke et al. (2011): +/- $11.7 \mathrm{~m}$ for T-sheets and +/- $5.5 \mathrm{~m}$ for aerial photographs. This returns the maximum amount of variation possible in mapping, making this a highly conservative estimation of mapping error. Uncertainty in changes in areal extent and tidal prism were calculated as the square root of the sum of squares of the T-sheet area/tidal prism and the corresponding 2009 value. 
Tidal prism is alternately defined as the volume of water that moves through an inlet during an average flood or ebb stage of a tidal cycle, or as the difference in water volume in a tidal area (backbarrier, estuary, etc.) between high and low tide (Hume, 2005). For our analyses we define $\mathrm{TP}^{*}$, a proxy for tidal prism, as:

$$
\mathrm{TP} *\left(\mathrm{~m}^{3}\right)=\mathrm{TR}(\mathrm{m}) *\left[\text { Open Water Area }\left(\mathrm{m}^{2}\right)+\left(\operatorname{Intertidal} \text { Area }\left(\mathrm{m}^{2}\right) * \mathrm{k}\right)\right](1)
$$

where TR is the spring tidal range $(1.4 \mathrm{~m})$ and $\mathrm{k}$ is a geographically specific constant representing the proportion of each tidal cycle that the average intertidal area (salt marshes and tidal flats) is submerged, estimated at 0.15 based on marsh flooding frequencies from Walters and Kirwan (2016). Backbarrier marsh and open-water area errors were determined in the same manner as shoreline position error (i.e. perimeter multiplied by shoreline uncertainty) and propagated to $\mathrm{TP}^{*}$ error.

Table DR1. Data sources for historical marsh and open-water areas along the Virginia Barrier Islands.

\begin{tabular}{lll}
\hline T-Sheet ID* & Year & Spatial Coverage \\
\hline T00464 & 1854 & Southern Metompkin Island and northern Cedar Island \\
T00492 & 1855 & Wallops, Assawoman, and northern Metompkin Islands \\
T00509 & 1852 & Smith, Myrtle, Ship Shoal, and southern Mockhorn Islands \\
T01200 & 1871 & Hog, Parramore, and southern Cedar Islands \\
T01201 & 1869 & Cobb Island \\
T1202B & 1871 & Ship Shoal, Wreck, and Mockhorn Islands (all partial coverage) \\
T1204 & 1871 & Machipongo River \\
POG30-00-1895 & 1895 & Mockhorn Island (Public Oyster Grant chart) \\
\hline - note that Table DR1 only contains data sources used to map marsh and open water areas. We \\
irect the reader to Himmelstoss et al. (2010) for a list of the sources used in that study to \\
compile the shoreline dataset (of which we used the "Delmarva south" portion in this study).
\end{tabular}

\section{Supplemental Results and Discussion}

\subsection{Shoreline Retreat}

Values for the long- (1850/1-2010) and short- (1850/1-1910/1; 1980-2010) term islandaveraged and system-wide shoreline-retreat rates are provided in Table DR2.

Previous studies of shoreline change along the Virginia barrier islands works have spanned from high-resolution investigations of changes along individual islands within the system (e.g., Fenster and Dolan, 1996; Fenster and Hayden, 2007; Richardson, 2012; Richardson and McBride, 2007, 2011; Nebel et al., 2012; McBride et al., 2015; Richardson et al., 2015), to 
larger-scale studies of the entire barrier system (Rice et al., 1976; Dolan et al., 1979), to integrative investigation of the southern Delmarva Peninsula as a whole (Hapke et al., 2011). Our results compare favorably with these (Table DR3).

For example, our data indicate that the average system-wide (Metompkin to Smith islands) shoreline-retreat rate in the period of $1850 / 1$ to $20105.1 \mathrm{~m} \mathrm{yr}^{-1}$ (Table DR2). This is consistent with system-wide $20^{\text {th }}$ century estimates of $c a .5 \mathrm{~m} \mathrm{yr}^{-1}$ (Leatherman et al., 1982). More recent estimates (Hapke et al., 2011, 2013) are lower (2.9 $\mathrm{m} \mathrm{yr}^{-1 ;}$ 1850s-1997). This same mis-match is observed in the short-term shoreline-change rates: average system-wide short-term shoreline retreat was determined here to be $7.0 \mathrm{~m} \mathrm{yr}^{-1}$ but only $2.7 \mathrm{~m} \mathrm{yr}^{-1}$ by Hapke et al. (2011, 2013). It is noted that the "short-term" rates of Hapke et al. $(2011,2013)$ covers an earlier period than our study and a different geographic range: the region studied by Hapke et al. $(2011,2013)$ incorporates both barrier islands and mainland beach (the former have experienced shoreline change rates of $\sim 7 \mathrm{x}$ those of the latter), as well as the developed and largely stabilized shorelines of Wallops Island, Virginia outer coast south of the Chesapeake Bay mouth (i.e., Virginia Beach and Sandbridge), and the accretionary Fisherman's Island immediately south of our study area (Figure 1a).

These differences in coverage are particularly critical in comparisons of short-term rates: an increase in short-term shoreline-change rates as compared to long-term rates has been well documented along much of the Delmarva Peninsula and the VBIs (Richardson and McBride, 2007, 2011; Nebel et al., 2012), particularly in the early $21^{\text {st }}$ century (Richardson, 2012). This acceleration, observed for both our system-wide data and along most individual VBI (section 2.2.2), has been attributed to causes including impacts from more frequent tropical storm and hurricanes, updrift sediment trapping at Fishing Point on the southern end of Assateague Island, and acceleration in relative sea-level rise (Rice and Leatherman, 1983; Gaunt, 1991; Fenster et al., 1993; Richardson and McBride, 2007, 2011; Richardson, 2012; Nebel et al., 2012; McBride et al., 2015; Richardson et al., 2015). Thus, even in regions of overlap, the earlier timeframe captured in the "short-term" shoreline-change rates of Hapke et al. $(2011,2013)$ fails to capture the most recent 10 years of acceleration included in our much higher rate. 
Table DR2. Long-term, short-term, and change in shoreline change rates for Virginia Barrier Islands.

\begin{tabular}{|c|c|c|c|c|}
\hline Island & $\begin{array}{l}\text { Long-Term } \\
(1851 / 2-2010) \\
\text { Barrier Retreat } \\
\text { Rate }\left(\mathrm{m} \mathrm{yr}^{-1}\right)\end{array}$ & $\begin{array}{l}\text { Short-Term Early } \\
(1851 / 2-1910 / 1) \\
\text { Barrier Retreat } \\
\text { Rate }\left(\mathrm{m} \mathrm{yr}^{-1}\right)^{\dagger}\end{array}$ & $\begin{array}{l}\text { Short-Term Recent } \\
(1980-2010) \text { Barrier } \\
\text { Retreat Rate }\left(\mathrm{m} \mathrm{yr}^{-1}\right)\end{array}$ & $\begin{array}{l}\text { Difference: } \\
\text { Early to Late } \\
\text { Barrier Retreat } \\
\text { Rate }\left(\mathrm{m} \mathrm{yr}^{-1}\right)^{\ddagger}\end{array}$ \\
\hline Wallops* & $0.5 \pm 0.01$ & $-0.8 \pm 0.17$ & $-10.4 \pm 0.34$ & $-9.6 \pm 0.38$ \\
\hline Assawoman* & $3.6 \pm 0.09$ & $0.2 \pm 0.84$ & $4.0 \pm 0.19$ & $3.8 \pm 0.86$ \\
\hline Metompkin & $6.2 \pm 0.03$ & $3.6 \pm 0.03$ & $10.9 \pm 1.03$ & $7.3 \pm 1.03$ \\
\hline Cedar & $5.0 \pm 0.02$ & $5.5 \pm 0.31$ & $10.8 \pm 0.45$ & $5.3 \pm 0.55$ \\
\hline Parramore & $4.5 \pm 0.02$ & $-3.0 \pm 0.28$ & $12.4 \pm 0.30$ & $15.4 \pm 0.41$ \\
\hline Hog & $1.2 \pm 0.03$ & $2.5 \pm 0.61$ & $-1.3 \pm 0.32$ & $-3.8 \pm 0.69$ \\
\hline Cobb & $2.1 \pm 0.04$ & $10.2 \pm 3.56$ & $3.2 \pm 2.59$ & $-7.0 \pm 4.40$ \\
\hline Wreck & $4.9 \pm 0.16$ & $16.8 \pm 0.03$ & $4.2 \pm 1.00$ & $-12.6 \pm 1.00$ \\
\hline Ship Shoal & $3.8 \pm 0.43$ & $-3.2 \pm 2.50$ & $6.0 \pm 4.75$ & $9.2 \pm 5.36$ \\
\hline Myrtle & $6.0 \pm 0.12$ & $9.7 \pm 0.77$ & $19.3 \pm 5.67$ & $9.6 \pm 5.72$ \\
\hline Smith & $5.7 \pm 0.01$ & $5.2 \pm 0.08$ & $2.8 \pm 0.33$ & $-2.5 \pm 0.34$ \\
\hline All VBIs & $5.1 \pm 0.01$ & $2.9 \pm 0.04$ & $7.0 \pm 0.07$ & $4.2 \pm 0.08$ \\
\hline \multicolumn{5}{|c|}{$\begin{array}{l}{ }^{\dagger} \text { - positive values indicate retreat (westward shoreline movement); negative values indicate } \\
\text { advance (eastward shoreline movement) } \\
\ddagger \text { - positive values indicate acceleration in migration; negative values indicate deceleration }\end{array}$} \\
\hline
\end{tabular}

\subsection{Marsh, Open-Water, and Tidal Prism Changes}

Values for barriershed-integrated historical (1870) and modern (2009) marsh, openwater, and backbarrier areas along the Virginia barrier islands are provided in Table DR4. Calculated historical and modern values for TP* are also provided, along with calculated changes in these values between historical and modern time periods. Finally, marsh area gain/loss in each of these systems are also provided in Table DR4 and presented visually for the entire Virginia barrier islands system in Figure DR1. These results are used as inputs for Figure 2 of the article and summarized and discussed in the main article body text. Table DR5 presents these same area and TP* changes, except separated by "bayshed" (approximate area flooded and drained by a given tidal inlet). Bayshed extents and changes in TP* for each bayshed (18702009) are shown in Figure DR1a. 
Table DR3. Comparison of island-integrated shoreline retreat and/or advance rates from this study and earlier works. Positive values indicate retreat (westward shoreline movement); negative values indicate advance (eastward shoreline movement). Shoreline-change rates are only provided if given as island-wide rates in original studies.

\begin{tabular}{|c|c|c|c|c|c|}
\hline Island & $\begin{array}{l}\text { Time period } \\
\text { covered }\end{array}$ & $\begin{array}{l}\text { Length of } \\
\text { Record (yrs) }\end{array}$ & $\begin{array}{l}\text { Description of } \\
\text { length }\end{array}$ & Rate & Source \\
\hline \multirow{5}{*}{ Wallops } & $1852-1974$ & 122 & Long-term early & 1.5 & Dolan et al., 1979 \\
\hline & $1852-1974$ & 122 & Long-term early & 2.0 & Leatherman et al., 1982 \\
\hline & 1852-2010 & 158 & Long-term & $0.5 \pm 0.01$ & this study \\
\hline & $1852-1910$ & 58 & Short-term early & $-0.8 \pm 0.17$ & this study \\
\hline & 1980-2010 & 30 & Short-term recent & $-10.4 \pm 0.34$ & this study \\
\hline \multirow[t]{5}{*}{ Assawoman } & 1852-1974 & 122 & Long-term early & 3.1 & Dolan et al., 1979 \\
\hline & 1852-1974 & 122 & Long-term early & 3.5 & Leatherman et al., 1982 \\
\hline & 1852-2010 & 158 & Long-term & $3.6 \pm 0.09$ & this study \\
\hline & 1852-1910 & 58 & Short-term early & $0.2 \pm 0.84$ & this study \\
\hline & 1980-2010 & 30 & Short-term recent & $4.0 \pm 0.19$ & this study \\
\hline \multirow[t]{7}{*}{ Metompkin } & 1852-1955 & 103 & Long-term early & 4.7 & Rice et al., 1976 \\
\hline & 1852-1974 & 122 & Long-term early & 6.9 & Dolan et al., 1979 \\
\hline & 1852-1974 & 122 & Long-term early & 5.0 & Leatherman et al., 1982 \\
\hline & $1852-2010$ & 158 & Long-term & $6.2 \pm 0.03$ & this study \\
\hline & 1852-1910 & 58 & Short-term early & $3.6 \pm 0.03$ & this study \\
\hline & $1955-1968$ & 13 & Short-term intermediate & 5.4 & Rice et al., 1976 \\
\hline & 1980-2010 & 30 & Short-term recent & $10.9 \pm 1.03$ & this study \\
\hline \multirow[t]{14}{*}{ Cedar } & 1852-1968 & 116 & Long-term early & 5.1 & Rice et al., 1976 \\
\hline & 1852-1974 & 122 & Long-term early & 3.9 & Dolan et al., 1979 \\
\hline & 1852-1974 & 122 & Long-term early & 4.9 & Leatherman et al., 1982 \\
\hline & $1852-2007$ & 155 & Long-term & $5.5 \pm 0.1$ & Richardson, 2012; Richardson and McBride, 2011 \\
\hline & $1852-2007$ & 155 & Long-term & 4.1 & Nebel et al., 2012 \\
\hline & $1852-2010$ & 158 & Long-term & $5.0 \pm 0.02$ & this study \\
\hline & $1852-2010$ & 158 & Long-term & 6.1 & Richardson, 2012 \\
\hline & $1852-1910$ & 58 & Short-term early & $5.5 \pm 0.31$ & this study \\
\hline & 1910-1962 & 52 & Short-term intermediate & 3.0 & Nebel et al., 2012 \\
\hline & 1910-1986 & 76 & Short-term intermediate & 4.4 & Gaunt, 1991 \\
\hline & $1962-2007$ & 45 & Short-term recent & 7.2 & Nebel et al., 2012 \\
\hline & 1980-2010 & 30 & Short-term recent & $10.8 \pm 0.45$ & this study \\
\hline & 1994-2007 & 13.0 & Short-term recent & 12.6 & Nebel et al., 2012 \\
\hline & 2007-2010 & 3 & Short-term modern & $15.4 \pm 0.1$ & Richardson, 2012; Richardson and McBride, 2011 \\
\hline \multirow[t]{5}{*}{ Parramore } & 1852-1974 & 122 & Long-term early & 4.5 & Dolan et al., 1979 \\
\hline & 1852-1998 & 146 & Long-term & 4.1 & Richardson, 2012 \\
\hline & 1852-2006 & 154 & Long-term & $3.6 \pm 0.1$ & Richardson and McBride, 2007 \\
\hline & $1852-2010$ & 158 & Long-term & $4.5 \pm 0.02$ & this study \\
\hline & $1852-2010$ & 158 & Long-term & 5.0 & Richardson, 2012 \\
\hline
\end{tabular}




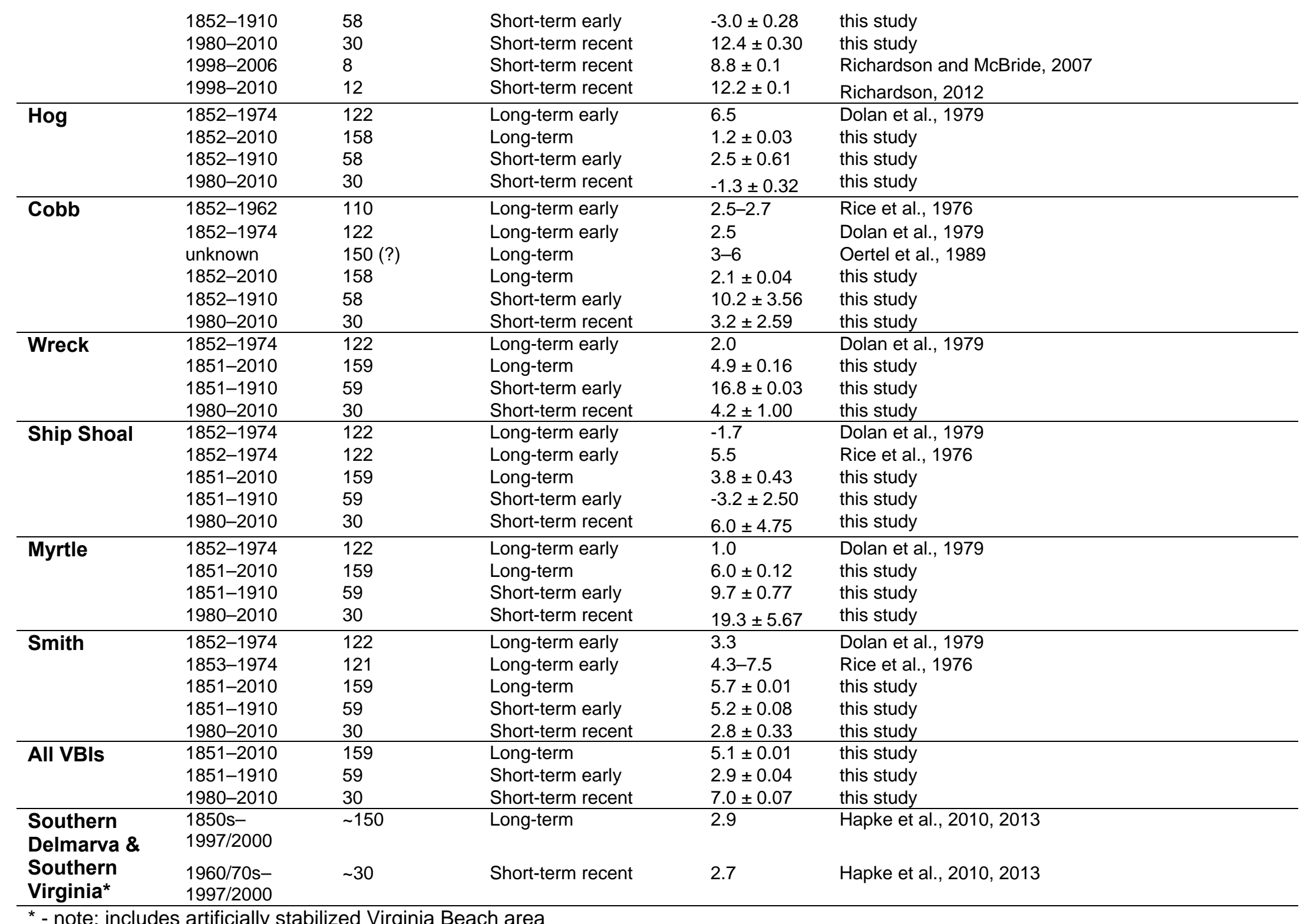

* - note: includes artificially stabilized Virginia Beach area 
Table DR4. Characteristics of backbarrier environments of Virginia barrier islands through time. Positive values indicate net gains. Note that "Marsh buried by barrier (for a given island)" refers to marsh buried by the migration of a single island, whereas

"Barriershed marsh buried by barrier" refers to the amount of marsh buried within an island's barriershed, which is defined as the sum of the two baysheds (Table DR5) bounding each island, and therefore includes marsh buried on adjacent islands.

\begin{tabular}{|c|c|c|c|c|c|c|c|c|c|}
\hline $\begin{array}{l}\text { Barrier } \\
\text { Island }\end{array}$ & $\begin{array}{l}1870 \\
\text { Barriershed } \\
\text { Water Area } \\
\left(\mathrm{km}^{2}\right)\end{array}$ & $\begin{array}{l}1870 \\
\text { Barriershed } \\
\text { Marsh Area } \\
\left(\mathrm{km}^{2}\right)\end{array}$ & $\begin{array}{l}1870 \text { Total } \\
\text { Barriershed } \\
\text { Area }\left(\mathrm{km}^{2}\right)\end{array}$ & $\begin{array}{l}2009 \\
\text { Barriershed } \\
\text { Water Area } \\
\left(\mathbf{k m}^{2}\right)\end{array}$ & $\begin{array}{l}2009 \\
\text { Barriershed } \\
\text { Marsh Area } \\
\left(\mathrm{km}^{2}\right)\end{array}$ & $\begin{array}{l}2009 \text { Total } \\
\text { Barriershed } \\
\text { Area }\left(\mathrm{km}^{2}\right)\end{array}$ & $\begin{array}{l}\text { Change in } \\
\text { Marsh Area } \\
\left(\mathrm{km}^{2}\right)\end{array}$ & $\begin{array}{l}\text { Change } \\
\text { in Water } \\
\text { Area } \\
\left(\mathrm{km}^{2}\right)\end{array}$ & $\begin{array}{l}\text { Change in } \\
\text { total back- } \\
\text { barrier } \\
\text { area }\left(\mathrm{km}^{2}\right)\end{array}$ \\
\hline Metompkin & $31.5 \pm 4.5$ & $46.3 \pm 2.5$ & $77.7 \pm 2.5$ & $22.3 \pm 1.8$ & $34.8 \pm 1.1$ & $57.1 \pm 1.1$ & $-11.4 \pm 4.9$ & $-9.2 \pm 2.7$ & $-20.6 \pm 2.7$ \\
\hline Cedar & $64.4 \pm 5.5$ & $77.3 \pm 3.5$ & $141.7 \pm 2.5$ & $63.0 \pm 2.4$ & $66.2 \pm 1.6$ & $129.2 \pm 1.2$ & $-11.1 \pm 6.0$ & $-1.4 \pm 3.8$ & $-12.5 \pm 2.8$ \\
\hline Parramore & $98.9 \pm 5.2$ & $97.3 \pm 4.5$ & $196.2 \pm 1.5$ & $112.4 \pm 2.4$ & $84.0 \pm 2.0$ & $196.4 \pm 0.9$ & $-13.3 \pm 5.7$ & $13.5 \pm 5.0$ & $0.2 \pm 1.8$ \\
\hline Hog & $202.6 \pm 6.5$ & $98.5 \pm 5.2$ & $301.1 \pm 2.4$ & $215.3 \pm 2.9$ & $81.6 \pm 2.2$ & $296.9 \pm 1.3$ & $-16.9 \pm 7.2$ & $12.7 \pm 5.6$ & $-4.2 \pm 2.8$ \\
\hline Cobb & $227.1 \pm 7.2$ & $115.3 \pm 5.6$ & $342.4 \pm 2.8$ & $245.3 \pm 3.2$ & $87.2 \pm 2.4$ & $332.4 \pm 1.5$ & $-28.1 \pm 7.9$ & $18.2 \pm 6.1$ & $-10 \pm 3.2$ \\
\hline Wreck & $98.3 \pm 3.6$ & $70.8 \pm 2.9$ & $169.0 \pm 1.2$ & $109.7 \pm 1.5$ & $46.5 \pm 1.2$ & $156.2 \pm 0.6$ & $-24.2 \pm 3.9$ & $11.4 \pm 3.2$ & $-12.8 \pm 1.3$ \\
\hline Ship Shoal & $34.8 \pm 1.7$ & $40.9 \pm 1.5$ & $75.6 \pm 0.6$ & $33.3 \pm 0.6$ & $31.4 \pm 0.5$ & $64.7 \pm 0.3$ & $-9.5 \pm 1.8$ & $-1.5 \pm 1.6$ & $-10.9 \pm 0.6$ \\
\hline Myrtle & $27.7 \pm 1.7$ & $35.2 \pm 1.6$ & $62.9 \pm 0.5$ & $19.8 \pm 0.5$ & $33.1 \pm 0.4$ & $52.9 \pm 0.2$ & $-2.0 \pm 1.8$ & $-7.9 \pm 1.7$ & $-9.9 \pm 0.5$ \\
\hline Smith & $56.1 \pm 2.5$ & $26.7 \pm 1.6$ & $82.8 \pm 1.3$ & $44.3 \pm 1.0$ & $26.2 \pm 0.6$ & $70.5 \pm 0.5$ & $-0.5 \pm 2.7$ & $-11.8 \pm 1.8$ & $-12.3 \pm 1.4$ \\
\hline All islands & $448.3 \pm 20.6$ & $326.5 \pm 15.1$ & $774.8 \pm 7.1$ & $457.0 \pm 8.6$ & $264.0 \pm 6.3$ & $721.0 \pm 3.5$ & $-62.9 \pm 22.4$ & $9.2 \pm 16.3$ & $-53.7 \pm 8.0$ \\
\hline
\end{tabular}

Table DR4 continued.

\begin{tabular}{|c|c|c|c|c|c|c|}
\hline $\begin{array}{l}\text { Barrier } \\
\text { Island }\end{array}$ & $\begin{array}{l}1870 \mathrm{TP}^{*} \\
\left(\times 10^{6} \mathrm{~m}^{3}\right)\end{array}$ & $\begin{array}{l}2009 \mathrm{TP}^{*} \\
\left(\times 10^{6} \mathrm{~m}^{3}\right)\end{array}$ & $\begin{array}{l}\Delta \mathrm{TP}^{*} \\
\left(\mathrm{x} 10^{6} \mathrm{~m}^{3}\right)\end{array}$ & $\begin{array}{l}\text { Marsh buried by } \\
\text { barrier (for a given } \\
\text { island) }\left(\mathrm{km}^{2}\right)\end{array}$ & $\begin{array}{l}\text { Barriershed marsh } \\
\text { buried by barrier }\left(\mathrm{km}^{2}\right)\end{array}$ & $\begin{array}{l}\text { Barriershed Interior } \\
\text { Marsh Change }\left(\mathrm{km}^{2}\right)\end{array}$ \\
\hline Metompkin & $53.8 \pm 4.4$ & $38.5 \pm 1.9$ & $-15.3 \pm 4.8$ & $-7.9 \pm 0.6$ & $-13.2 \pm 1.0$ & $1.8 \pm 4.4$ \\
\hline Cedar & $106.4 \pm 6.0$ & $102.1 \pm 2.7$ & $-4.3 \pm 6.6$ & $-4.9 \pm 0.4$ & $-10.3 \pm 0.8$ & $-0.8 \pm 5.6$ \\
\hline Parramore & $158.9 \pm 7.4$ & $175 \pm 3.3$ & $16.1 \pm 8.1$ & $-0.1 \pm 0.0$ & $-3.5 \pm 0.3$ & $-9.9 \pm 5.7$ \\
\hline Hog & $304.4 \pm 8.6$ & $318.6 \pm 3.7$ & $14.2 \pm 9.4$ & $-1.3 \pm 0.2$ & $-1.7 \pm 0.4$ & $-15.2 \pm 7.1$ \\
\hline Cobb & $342.2 \pm 9.4$ & $361.7 \pm 4.1$ & $19.5 \pm 10.2$ & $-2.0 \pm 0.3$ & $-4.3 \pm 0.6$ & $-23.8 \pm 7.6$ \\
\hline Wreck & $152.4 \pm 4.8$ & $163.3 \pm 2.1$ & $10.9 \pm 5.3$ & $-4.1 \pm 0.2$ & $-5.0 \pm 0.6$ & $-19.2 \pm 3.5$ \\
\hline Ship Shoal & $57.3 \pm 2.5$ & $53.2 \pm 0.8$ & $-4.1 \pm 2.6$ & $-2.8 \pm 0.2$ & $-6.5 \pm 0.5$ & $-3.0 \pm 1.6$ \\
\hline Myrtle & $46.2 \pm 2.6$ & $34.7 \pm 0.7$ & $-11.5 \pm 2.7$ & $-1.9 \pm 0.1$ & $-6.4 \pm 0.4$ & $4.4 \pm 1.6$ \\
\hline Smith & $84.1 \pm 2.8$ & $67.5 \pm 1.1$ & $-16.6 \pm 3.0$ & $-7.3 \pm 0.8$ & $-8.8 \pm 0.9$ & $8.3 \pm 2.1$ \\
\hline All islands & $696.2 \pm 25.4$ & $695.9 \pm 10.6$ & $-0.3 \pm 27.6$ & $-32.3 \pm 3.4$ & $-32.3 \pm 3.4$ & $-30.6 \pm 20.5$ \\
\hline
\end{tabular}


Table DR5. Characteristics of backbarrier environments of Virginia barrier islands separated by inlet bayshed (area drained by a given tidal inlet) through time. Positive values indicate net gains. Note that baysheds of southern four islands (Wreck, Myrtle, Ship Shoal, and Smith islands) are combined into a single bayshed for a more representative comparison to other baysheds.

\begin{tabular}{|c|c|c|c|c|c|c|c|c|}
\hline Tidal Inlet & $\begin{array}{l}\text { Associated } \\
\text { barrier } \\
\text { islands }\end{array}$ & $\begin{array}{l}\text { Bayshed } \\
\text { total marsh } \\
\text { change } \\
\left(\mathrm{km}^{2}\right)\end{array}$ & $\begin{array}{l}\text { Bayshed } \\
\text { barrier-driven } \\
\text { marsh } \\
\text { change }\left(\mathrm{km}^{2}\right)\end{array}$ & $\begin{array}{l}\text { Bayshed } \\
\text { interior } \\
\text { marsh } \\
\text { change } \\
\left(\mathrm{km}^{2}\right)\end{array}$ & $\begin{array}{l}1870 \\
\text { bayshed } \\
\text { TP* }^{*} \\
\left(\times 10^{6} \mathrm{~m}^{3}\right)\end{array}$ & $\begin{array}{l}2009 \\
\text { bayshed } \\
\text { TP* }^{*} \\
\left(\times 10^{6} \mathrm{~m}^{3}\right)\end{array}$ & $\begin{array}{l}\text { Change } \\
\text { in } \\
\text { bayshed } \\
\mathrm{TP}^{*} \\
\left(\times 10^{6} \mathrm{~m}^{3}\right)\end{array}$ & $\begin{array}{l}\text { Change in } \\
\text { bayshed } \\
\text { TP* }^{*}(\%)\end{array}$ \\
\hline Gargathy Inlet & $\begin{array}{l}\text { Assawoman- } \\
\text { Metompkin }\end{array}$ & $-6.8 \pm 2.3$ & $-6.1 \pm 2.1$ & $-0.7 \pm 1.0$ & $17.2 \pm 2.2$ & $13.4 \pm 1.0$ & $-3.8 \pm 2.4$ & $-22.2 \pm 14.0$ \\
\hline Metompkin Inlet & $\begin{array}{l}\text { Metompkin- } \\
\text { Cedar }\end{array}$ & $-4.6 \pm 2.7$ & $-7.1 \pm 2.1$ & $2.4 \pm 1.1$ & $36.6 \pm 2.2$ & $25.1 \pm 1.0$ & $-11.5 \pm 2.4$ & $-31.4 \pm 6.6$ \\
\hline $\begin{array}{l}\text { Wachapreague } \\
\text { Inlet }\end{array}$ & $\begin{array}{l}\text { Cedar- } \\
\text { Parramore }\end{array}$ & $-6.5 \pm 3.5$ & $-3.2 \pm 0.2$ & $-3.3 \pm 3.4$ & $69.8 \pm 3.9$ & $77.0 \pm 1.8$ & $7.2 \pm 4.3$ & $10.3 \pm 6.2$ \\
\hline Quinby Inlet & $\begin{array}{l}\text { Parramore- } \\
\text { Hog }\end{array}$ & $-6.9 \pm 2.6$ & $-0.3 \pm 2.4$ & $-6.6 \pm 1.0$ & $89.1 \pm 3.6$ & $98.0 \pm 1.5$ & $8.9 \pm 3.9$ & $10.0 \pm 4.4$ \\
\hline $\begin{array}{l}\text { Great } \\
\text { Machipongo } \\
\text { Inlet }\end{array}$ & Hog-Cobb & $-10.0 \pm 4.7$ & $-1.5 \pm 4.1$ & $-8.6 \pm 1.9$ & $215.3 \pm 5.6$ & $220.5 \pm 2.4$ & $5.3 \pm 6.1$ & $2.5 \pm 2.8$ \\
\hline Sand Shoal Inlet & Cobb-Wreck & $-18.1 \pm 3.4$ & $-2.9 \pm 3.0$ & $-15.2 \pm 1.4$ & $126.9 \pm 4.2$ & $141.1 \pm 1.8$ & $14.2 \pm 4.6$ & $11.2 \pm 3.6$ \\
\hline $\begin{array}{l}\text { New / Wine / } \\
\text { Little/ Ship } \\
\text { Shoal/ and } \\
\text { Smith Island } \\
\text { inlets } \\
\text { (combined) }\end{array}$ & $\begin{array}{l}\text { Wreck- } \\
\text { Fishermans }\end{array}$ & $-10.0 \pm 2.6$ & $-15.3 \pm 2.0$ & $5.4 \pm 1.2$ & $141.4 \pm 3.1$ & $120.7 \pm 1.1$ & $20.7 \pm 3.2$ & $14.6 \pm 2.3$ \\
\hline \multicolumn{2}{|c|}{ VES Wide Total (sum of all inlets) } & $-62.9 \pm 22.4$ & $-36.3 \pm 3.4$ & $-26.6 \pm 20.5$ & $696.2 \pm 25.4$ & $695.9 \pm 10.6$ & $-0.3 \pm 27.6$ & $0.0 \pm 4.0$ \\
\hline
\end{tabular}


Figure DR1. A) Baysheds of the Virginia barrier islands. Values in parentheses are change in tidal prism (1870-2009; negative values represent decrease; data from Table DR5). Note large decreases in northern rollover-dominated islands and increases associated with backbarrier marsh loss in southern islands. Satellite image is modified from NASA Blue Marble i-cubed 15m eSAT imagery. B) overview and C)-E) zoom-in maps of marsh gain/loss associated with bay expansion, upland migration, and landward migration of Assawoman through Smith islands between mid/late-1800s and 2009. Dashed square in (B) shows region highlighted in Figure 1b-d.
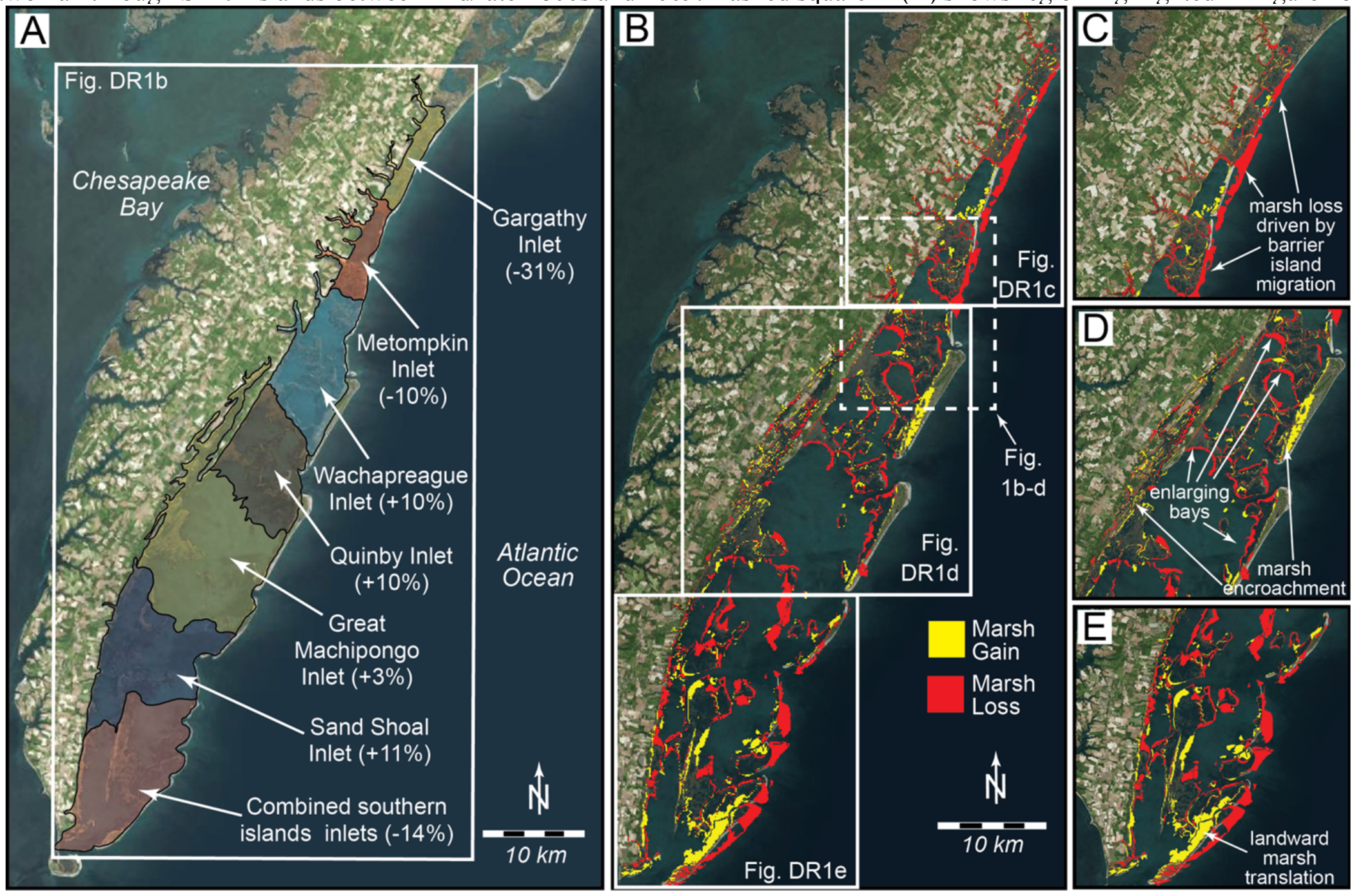


\subsection{Comparisons of Marsh Area Change with Results of Earlier Works}

Our work presents the longest ( $\mathrm{ca} .140$ years) synthesis of marsh-area change along the VBI, and the first to quantifiably relate these changes to tidal prism, especially at the system scale. A number of previous studies have sought to quantify changes in marsh and open-water area over shorter time periods (maximum 100 years; Knowlton, 1971) and within select subsections of the VBI (Knowlton, 1971; Kastler and Wiberg, 1996; Erwin et al., 2004; Sepanik and McBride, 2015) (Table DR6).

For example, Sepanik and McBride (2015) studied marsh change within the Wachapreague Inlet bayshed (southern Cedar Island and northern Parramore Island; Figure DR1) at two different time periods (1957-1994 and 1994-2012). They found that barrier migration played an outsized role in marsh loss, accounting for 45\% of loss between 1957 and 2012 . Moreover, whereas burial and exposure were responsible for the large majority of loss within the section of the bayshed fronted by the Cedar Island, overwash played almost no role in marsh loss within the section of the bayshed fronted by Parramore Island, which has historically been stable to erosional along its northern end. Marsh loss in this southern half of the bayshed was caused primarily by wind-driven waves and tidal currents.

We find that that our $2009 \mathrm{TP}^{*}$ value for the bayshed of Wachapreague Inlet (Figure DR1a) $\left(75-79 \times 10^{6} \mathrm{~m}^{3}\right)$ is similar to the tidal prism calculated by Richardson et al. (2015) for $2010\left(50-65 \times 10^{6} \mathrm{~m}^{3}\right)$. Furthermore, we find that $\mathrm{TP}^{*}$ increased by $10.5 \%$ between 1870 and 2009 (Table DR5), a value that also compares favorably to earlier studies of the change in Wachapreague Inlet tidal prism (+6.6\% for $1871-2013$; $+5.8 \%$ for $2007-2013$; Fenster et al., 2011; Richardson et al., 2015). Differences in our results and those of earlier studies are largely methodological: we apply a simple formula based on marsh and open-water area at both time periods to calculate changes in a proxy for tidal prism, whereas Fenster et al. (2011), Richardson (2012) and Richardson et al. (2015) rely on inlet cross-sectional-area / tidal-prism relationships for earlier time periods and direct measurement of water flow through the inlet for recent periods to calculate tidal prism volumes.

Similarities extend to marsh area changes: we observe the same spatial diversity in responsible mechanisms for marsh loss as Sepanik and McBride (2015) between the northern and southern halves of the Wachapreague Inlet bayshed (Table DR6; Figure 1d). We also find nearly equal losses in marsh from 1870 to 2009 due both to barrier island migration $\left(3.2 \mathrm{~km}^{2}\right.$; 
$49 \%)$ and backbarrier processes $\left(3.3 \mathrm{~km}^{2} ; 51 \%\right)$, also with a small predominance of the latter. By contrast, our calculated overall marsh-loss rate of $0.08 \% \mathrm{yr}^{-1}\left(0.05 \mathrm{~km}^{2} \mathrm{yr}^{-1}\right)$ for the period $1870-2009$ is only $1 / 3$ of those calculated for the more recent 55 -year period, indicating an average increase of more than an order of magnitude during the latter $20^{\text {th }}$ and early $21^{\text {st }}$ centuries as compared with the late 1800s and early 1900s. However, this value is likely partially inflated. Even assuming no methodological differences and $100 \%$ overlap in spatial coverage, the record of McBride and Sepanik (2015) starts 87 years after ours. Given that marsh loss has been an ongoing process in the Virginia barrier islands since at least the $19^{\text {th }}$ century, Sepanik and McBride (2015) will have a smaller starting marsh area, and their loss rates as a percent of that area will appear higher than ours.

Yet, it is also probable that much of the observed acceleration in marsh loss is real. Sepanik and McBride (2015) observed a 160\% increase in marsh loss rates for this same area between 1957-1994 and 1994-2012. Likewise, Erwin et al. (2004) found that interior marsh retreat at Curlew Bay, located within Wachapreague Inlet bayshed, increased 3.5x due to edge erosion during a similar time period (1949-1967 and 1967-1994) (Table DR6). However, given the overwhelming role of burial and exposure in marsh loss along Cedar Island, this increase can also be attributed to a recent acceleration in shoreline retreat (see section 2.2). Indeed, Sepanik and McBride (2015) documented a nearly 3x increase in barrier-driven marsh loss in the Wachapreague Inlet bayshed between 1957-1994 and 1994-2012 records (Table DR6). Extrapolating these findings into the late $19^{\text {th }}$ and early $20^{\text {th }}$ centuries, Gaunt (1991) surmised that Cedar Island transitioned from erosional to migrational in the early 1960s. Hence, it is reasonable that acceleration in marsh loss can be attributed to the onset of wide-scale overwash and front-side exposure of marsh in the northern half if the Wachapreague Inlet bayshed. 
Table DR6. Comparison of rates of change of marsh and open-water area from this study and earlier works.

\begin{tabular}{|c|c|c|c|c|c|c|c|c|c|c|c|}
\hline \multirow[b]{2}{*}{$\begin{array}{l}\text { Spatial } \\
\text { Coverage }\end{array}$} & \multirow[b]{2}{*}{ Source } & \multirow[b]{2}{*}{$\begin{array}{l}\text { Years } \\
\text { studied }\end{array}$} & \multicolumn{3}{|c|}{ Total marsh change } & \multicolumn{3}{|c|}{ Barrier-driven change } & \multicolumn{3}{|c|}{ Non-barrier-driven change } \\
\hline & & & $\begin{array}{l}\text { Marsh } \\
\text { area } \\
\text { change } \\
\text { km }^{2}\end{array}$ & $\begin{array}{l}\text { Area } \\
\text { change } \\
\text { rate } \\
\text { km }^{2} \mathbf{y r}^{-1}\end{array}$ & $\begin{array}{l}\text { Annual } \\
\text { percent } \\
\text { loss } \\
\% \mathrm{yr}^{-1}\end{array}$ & $\begin{array}{l}\text { Marsh } \\
\text { area } \\
\text { change } \\
\text { km }^{2}\end{array}$ & $\begin{array}{l}\text { Area } \\
\text { change } \\
\text { rate } \\
\text { km }^{2} \mathbf{y r}^{-1}\end{array}$ & $\begin{array}{l}\text { Annual } \\
\text { percent } \\
\text { loss } \\
\% \mathrm{yr}^{-1}\end{array}$ & $\begin{array}{l}\text { Marsh } \\
\text { area } \\
\text { change } \\
\text { km }^{2}\end{array}$ & $\begin{array}{l}\text { Area } \\
\text { change } \\
\text { rate } \\
\text { km }^{2} \mathbf{y r}^{-1}\end{array}$ & $\begin{array}{l}\text { Annual } \\
\text { percent } \\
\text { loss } \\
\% \mathrm{yr}^{-1}\end{array}$ \\
\hline $\begin{array}{l}\text { Wallops to } \\
\text { Fisherman's } \\
\text { islands }\end{array}$ & $\begin{array}{l}\text { Knowlton, } \\
1971\end{array}$ & $\begin{array}{l}1852 / 71- \\
1962\end{array}$ & -50.7 & -0.507 & $-0.16 \%$ & -33.0 & -0.33 & N/A & -17.7 & -0.18 & N/A \\
\hline $\begin{array}{l}\text { Chimney Pole } \\
\text { Marsh (behind } \\
\text { Hog Island) }\end{array}$ & $\begin{array}{l}\text { Kastler and } \\
\text { Wiberg, } 1996\end{array}$ & $1949-1990$ & N/A & $\mathrm{N} / \mathrm{A}$ & $\mathrm{N} / \mathrm{A}$ & N/A & $\mathrm{N} / \mathrm{A}$ & N/A & -0.8 & -0.020 & $-0.26 \%$ \\
\hline $\begin{array}{l}\text { Southern } \\
\text { Parramore Island } \\
\text { Marsh }\end{array}$ & $\begin{array}{l}\text { Kastler and } \\
\text { Wiberg, } 1996\end{array}$ & $1982-1990$ & N/A & N/A & N/A & -0.04 & -0.005 & $-0.90 \%$ & & $\mathrm{~N} / \mathrm{A}$ & N/A \\
\hline \multirow{3}{*}{$\begin{array}{l}\text { Curlew Bay (within } \\
\text { Wachapreague } \\
\text { Inlet Bayshed) }\end{array}$} & Erwin et al., & $1949-1967$ & N/A & N/A & N/A & N/A & $\mathrm{N} / \mathrm{A}$ & N/A & -0.1 & -0.004 & $-0.09 \%$ \\
\hline & 2004 & $1967-1994$ & N/A & N/A & $\mathrm{N} / \mathrm{A}$ & N/A & $\mathrm{N} / \mathrm{A}$ & N/A & -0.4 & -0.014 & $-0.32 \%$ \\
\hline & & $1949-1994$ & N/A & N/A & $\mathrm{N} / \mathrm{A}$ & N/A & $\mathrm{N} / \mathrm{A}$ & N/A & -0.5 & -0.011 & $-0.23 \%$ \\
\hline \multirow{3}{*}{$\begin{array}{l}\text { Gull Marsh } \\
\text { (behind Cobb } \\
\text { Island) }\end{array}$} & Erwin et al., & $1967-1975$ & N/A & N/A & N/A & N/A & $\mathrm{N} / \mathrm{A}$ & N/A & -0.3 & -0.032 & $-0.79 \%$ \\
\hline & 2004 & $1975-1994$ & N/A & N/A & N/A & N/A & $\mathrm{N} / \mathrm{A}$ & N/A & -0.4 & -0.023 & $-0.59 \%$ \\
\hline & & $1967-1994$ & N/A & N/A & N/A & N/A & $\mathrm{N} / \mathrm{A}$ & N/A & -0.7 & -0.026 & $-0.65 \%$ \\
\hline \multirow{3}{*}{$\begin{array}{l}\text { Mockhorn Island } \\
\text { (behind southern } \\
\text { VBI) }\end{array}$} & \multirow{3}{*}{$\begin{array}{l}\text { Erwin et al., } \\
2004\end{array}$} & $1949-1967$ & N/A & N/A & N/A & N/A & $\mathrm{N} / \mathrm{A}$ & N/A & 1.0 & 0.057 & $0.19 \%$ \\
\hline & & $1967-1994$ & N/A & N/A & $\mathrm{N} / \mathrm{A}$ & N/A & $\mathrm{N} / \mathrm{A}$ & N/A & 1.9 & 0.070 & $0.02 \%$ \\
\hline & & $1949-1994$ & N/A & N/A & $\mathrm{N} / \mathrm{A}$ & N/A & N/A & N/A & 1.2 & 0.026 & $0.09 \%$ \\
\hline Wachapreague & Sepanik and & $1957-2012$ & -5.9 & -0.107 & $-0.24 \%$ & -2.6 & -0.048 & $-0.55 \%$ & -3.2 & -0.059 & $-0.17 \%$ \\
\hline Inlet Bayshed & McBride, & $1957-1994$ & -3.4 & -0.093 & $-0.20 \%$ & -1.2 & -0.033 & $-0.35 \%$ & -2.2 & -0.059 & $-0.17 \%$ \\
\hline $\begin{array}{l}\text { (southern Cedar, } \\
\text { northern } \\
\text { Parramore) }\end{array}$ & 2015 & $1994-2012$ & -2.4 & -0.136 & $-0.32 \%$ & -1.4 & -0.077 & $-0.95 \%$ & -1.1 & -0.059 & $-0.17 \%$ \\
\hline $\begin{array}{l}\text { Wachapreague } \\
\text { Inlet Bayshed }\end{array}$ & This study & $1870-2009$ & -6.5 & -0.047 & $-0.09 \%$ & -3.2 & -0.023 & $-0.04 \%$ & -3.3 & -0.024 & $-0.04 \%$ \\
\hline $\begin{array}{l}\text { Assawoman to } \\
\text { Smith islands } \\
\text { (combined } \\
\text { system) }\end{array}$ & This study & $1870-2009$ & -62.8 & -0.452 & $-0.14 \%$ & -32.2 & -0.232 & $-0.07 \%$ & -30.6 & -0.220 & $-0.06 \%$ \\
\hline
\end{tabular}




\section{Supplemental References:}

Dolan, R., Hayden, B., and Jones, C., 1979, Barrier island configuration: Science, v. 204, p. 401403, doi:10.1126/science.204.4391.401-a.

Erwin, R.M., Sanders, G.M., and Prosser, D.J., 2004, Changes in lagoonal marsh morphology at selected northeastern Atlantic Coast sites of significance to migratory waterbirds: Wetlands, v. 24, p. 891-903, doi:10.1672/0277-5212(2004)024[0891:CILMMA]2.0.CO.

Fenster, M.S., and Bundick, J.A., 2015, Morphodynamics of Wallops Island, Virginia: A mixedenergy, human-modified barrier island, in chapter by: McBride, R.A., Fenster, M.S., Seminack, C.T., Richardson, T.M., Sepanik, J.M., Hanley, J.T., Bundick, J.A., and Tedder, E., Holocene barrier-island geology and morphodynamics of the Maryland and Virginia open-ocean coasts: Fenwick, Assateague, Chincoteague, Wallops, Cedar, and Parramore Islands, in: Brezinski, D.K., Halka, J.P., and Ortt, R.A., Jr. (editors), Tripping from the Fall Line: Field Excursions for the GSA Annual Meeting, Baltimore, 2015: Geological Society of America Field Guide 40, p. 392-401, doi:10.1130/2015.0040(10).

Fenster, M., and Dolan, R., 1996, Assessing the impact of tidal inlets on adjacent barrier island shorelines: Journal of Coastal Research, v. 12, p. 294-310.

Fenster, M., and Dolan, R., 1999, Mapping erosion hazard areas in the city of Virginia Beach: Journal of Coastal Research, v. 28, p. 58-68.

Fenster, M.S., and Hayden, B.P., 2007, Ecotone displacement trends on a highly dynamic barrier island: Hog Island, Virginia: Estuaries and Coasts, v. 30, p. 978-988, doi:10.1007/BF02841389.

Fenster, M.S., Dolan, R., and Elder, J.F., 1993, A new method for predicting shoreline positions from historical data: Journal of Coastal Research, v. 9, p. 147-171.

Fenster, M.S., McBride, R. A., Trembanis, A., Richardson, T., and Nebel, S.H., 2011, A field test of the theoretical evolution of a mixed-energy barrier coast to a regime of accelerated sea-level rise in: Wang, P., Rosati, J.D., and Roberts, T.M., eds., Coastal Sediments 2011: Proceedings of the Seventh International Symposium on Coastal Engineering and Science of Coastal Sediment Processes, World Scientific, p. 216-229, doi: 10.1142/9789814355537_0017.

Gaunt, C.H., 1991, Recent evolution and potential causal mechanisms of Cedar Island, Virginia, 1852-1986, in Kraus, N.C., Gingerich, K.J., and Kriebel, D.L., eds., Proceedings of the Specialty Conference on Quantitative Approaches to Coastal Sediment Processes: New York, NY, American Society of Civil Engineers, p. 2335-2349.

Hapke, C.J., Himmelstoss, E. A., Kratzmann, M., List, J.H., and Thieler, E.R., 2011, National assessment of shoreline change: historical shoreline change along the New England and MidAtlantic Coasts: U.S. Geological Survey Open-File Report 2010-1118, 57 p., http://pubs.usgs.gov/of/2010/1118/.

Hapke, C.J., Kratzmann, M.G. and Himmelstoss, E.A., 2013, Geomorphic and human influence on large-scale coastal change. Geomorphology, v. 199, p.160-170, doi:10.1016/j.geomorph.2012.11.025.

Hume, T.M., 2005, Tidal prism, in, Encyclopedia of Coastal Science: The Netherlands, Springer, p. 981-982. 
Kastler, J.A., and Wiberg, P.L., 1996, Sedimentation and Boundary Changes of Virginia Salt Marshes: Estuarine, Coastal and Shelf Science, v. 42, p. 683-700, doi:10.1006/ecss. 1996.0044.

Knowlton, S.M., 1971, Geomorphological history of tidal marshes, Eastern Shore, Virginia, from 1852-1966 [M.S. Thesis]: University of Virginia. 46 p.

Leatherman, S.P., Rice, T.E., and Goldsmith, V., 1982, Virginia Barrier Island configuration: A reappraisal: Science, v. 215, no. 4530, p. 285-287, doi:10.1126/science.215.4530.285.

McBride, R.A., Richardson, T.M., Fenster, M.S., and Seminack, C.T., 2015, Shoreline and ecogeomorphic changes along Parramore Island, Virginia: A mixed-energy, tide-dominated barrier island, in chapter by: McBride, R.A., Fenster, M.S., Seminack, C.T., Richardson, T.M., Sepanik, J.M., Hanley, J.T., Bundick, J.A., and Tedder, E., Holocene barrier-island geology and morphodynamics of the Maryland and Virginia open-ocean coasts: Fenwick, Assateague, Chincoteague, Wallops, Cedar, and Parramore Islands, in: Brezinski, D.K., Halka, J.P., and Ortt, R.A., Jr. (editors), Tripping from the Fall Line: Field Excursions for the GSA Annual Meeting, Baltimore, 2015: Geological Society of America Field Guide 40, p. 385-392, doi:10.1130/2015.0040(10).

Nebel, S.H., Trembanis, A.C., and Barber, D.C., 2012, Shoreline analysis and barrier island dynamics: Decadal scale patterns from Cedar Island, Virginia: Journal of Coastal Research, v. 28, p. 332-341, doi:10.2112/JCOASTRES-D-10-00144.1.

Oertel. G.F., Kearney, M.S., Leatherman, S.P., and Woo, H.-J., 1989, Anatomy of a barrier platform: outer barrier lagoon, southern Delmarva Peninsula, Virginia, in: Ward, L.G., and Ashley, G.M., eds., Physical Processes and Sedimentology of Siliciclastic-Dominate Lagoonal Systems: Marine Geology, v. 88, p. 303-318, doi:10.1016/0025-3227(89)90103-5.

Rice, T.E., and Leatherman, S.P., 1983, Barrier island dynamics: the Eastern Shore of Virginia: Southeastern Geology, v. 24, no. 3, p. 125-137.

Rice, T.E., Niedoroda, A.W., and Pratt, A.P., 1976, The coastal processes and geology: Virginia barrier islands: The Virginia Coast Reserve Study: Arlington, Virginia, The Nature Conservancy, p. 109-382.

Richardson, T.M., 2012, Morphodynamic changes of the Parramore-Cedar barrier island system and Wachapreague Inlet, Virginia from 1852 to 2011: a model of barrier island and tidal inlet evolution along the southern Delmarva Peninsula, USA [Ph.D. thesis]: Fairfax, George Mason University, $306 \mathrm{p}$.

Richardson, T.M., and McBride, R.A., 2007, Historical shoreline changes and morphodynamics of Parramore Island, Virginia (1852-2006), in: Kraus, N.C., and Rosati, J.D., eds., Coastal Sediments 2007: Proceedings of the Sixth International Symposium on Coastal Engineering and Science of Coastal Sediment Processes, American Society of Civil Engineers, p. 364377, doi:10.1061/9780784409268.

Richardson, T.M., and McBride, R.A., 2011, Historical shoreline changes and morphodynamics of Cedar Island, Virginia, USA: 1852-2010, in: Wang, P., Rosati, J.D., and Roberts, T.M., eds., Coastal Sediments 2011: Proceedings of the Seventh International Symposium on Coastal Engineering and Science of Coastal Sediment Processes, World Scientific, p. 12851299. 
Richardson, T.M., McBride, R.A., Fenster, M.S., and Seminack, C.T., 2015, Morphodynamic changes at Wachapreague Inlet, Virginia: A tide-dominated inlet system, in chapter by: McBride, R.A., Fenster, M.S., Seminack, C.T., Richardson, T.M., Sepanik, J.M., Hanley, J.T., Bundick, J.A., and Tedder, E., Holocene barrier-island geology and morphodynamics of the Maryland and Virginia open-ocean coasts: Fenwick, Assateague, Chincoteague, Wallops, Cedar, and Parramore Islands, in: Brezinski, D.K., Halka, J.P., and Ortt, R.A., Jr. (editors), Tripping from the Fall Line: Field Excursions for the GSA Annual Meeting, Baltimore, 2015: Geological Society of America Field Guide 40, p. 385-392, doi:10.1130/2015.0040(10).

Sepanik, J.M. and McBride, R.A., 2015, Salt-marsh loss in a barrier-island system: Parramore and Cedar Islands, Virginia, in chapter by: McBride, R.A., Fenster, M.S., Seminack, C.T., Richardson, T.M., Sepanik, J.M., Hanley, J.T., Bundick, J.A., and Tedder, E., Holocene barrier-island geology and morphodynamics of the Maryland and Virginia open-ocean coasts: Fenwick, Assateague, Chincoteague, Wallops, Cedar, and Parramore Islands, in: Brezinski, D.K., Halka, J.P., and Ortt, R.A., Jr. (editors), Tripping from the Fall Line: Field Excursions for the GSA Annual Meeting, Baltimore, 2015: Geological Society of America Field Guide 40, p. 392-401, doi:10.1130/2015.0040(10).

Thieler, E.R., Himmelstoss, E.A., Zichichi, J.L., and Ergul, Ayhan, 2008, Digital Shoreline Analysis System (DSAS) version 4.0-An ArcGIS extension for calculating shoreline change: U.S. Geological Survey Open-File Report 2008-1278, http://woodshole.er.usgs.gov/project-pages/DSAS/version4/.

Walters, D.C., and Kirwan, M.L., 2016, Optimal hurricane overwash thickness for maximizing marsh resilience to sea level rise: Ecology and Evolution, v. 6, p. 2948-2956, doi:10.1002/ece3.2024. 